\title{
Trichomonal vaginitis: evaluation of serological tests and identification of immunoreactive surface peptides
}

\author{
G SATAPATHY,* S K KAR, † J C SAMANTARAY $\ddagger$ S K PANDA $\S$
}

From the ${ }^{*}$ Division of Microbiology, National Institute of Communicable Diseases, Delhi, the $\dagger$ Regional Medical Research Centre (ICMR), Bhubaneswar, Orissa, and the Departments of $\ddagger$ Microbiology, and $\S$ Pathology, All India Institute of Medical Sciences, New Delhi, India

SUMMARY An indirect haemagglutination assay (IHA) with polysaccharide and protein antigens of Trichomonas vaginalis and an enzyme linked immunosorbent assay (ELISA) were used to test for antibodies against $T$ vaginalis in 58 women with trichonomal vaginitis and 48 with non-specific vaginitis. Eleven antibody positive sera were used in a radioimmunoprecipitation assay (RIPA) to identify surface peptides that elicited antibody responses in infected women. The serological tests were less sensitive than biological tests (smear examination and culture); antibodies were detected in 22 of the 58 women with trichomonal vaginitis by IHA using polysaccharide as antigen, in 27 by IHA using protein antigen, and in 36 by ELISA. The ELISA was also found to be of low specificity. Only two of the 11 sera tested by RIPA showed positive reactions with surface antigens, which were confirmed by autoradiography.

Trichomoniasis caused by the flagellate parasite Trichomonas vaginalis is one of the most common sexually transmitted diseases. ${ }^{12}$ It is characterised by severe inflammation of the vagina, foul smelling vaginal discharge, discomfort, and tissue cytopathology. ${ }^{34}$ In certain circumstances the patient may be symptomless or may have scanty vaginal discharge. ${ }^{56}$ The factors that determine the severity of the disease are still to be ascertained. Understanding of host humoral and cellular immune responses to this infection is incomplete. . $^{7-9}$

The triad of tests consisting of wet mount examination, culture, and acridine orange staining of the vaginal discharge, remains the main tool of laboratory diagnosis for trichonomiasis. ${ }^{10-12}$ Several serological tests-such as the indirect haemagglutination assay (IHA), complement fixation test (CFT), and the enzyme linked immunosorbent assay (ELISA)-have been developed for diagnosing trichomoniasis, but none has been widely evaluated and accepted. ${ }^{13-18}$ The nature of the antigens of $T$ vaginalis that provoke the serological response in man also remains unknown. Attempts at antigenic analysis have been made using monoclonal antibodies for detecting both species

Address for reprints: Dr S K Panda, Department of Pathology, All India Institute of Medical Sciences, New Delhi-1 10029, India

Accepted for publication 16 June 1987 specific and cross reacting antigens. ${ }^{1920}$ We undertook the present study to evaluate the efficacy of three serological tests in diagnosing $T$ vaginalis infection. We also attempted to characterise the surface protein antigens of the parasite responsible for the serological response.

\section{Patients and methods}

SELECTION OF PATIENTS AND CONTROLS

After obtaining their consent, we studied 106 women of childbearing age (15 to 47) attending the gynaecology outpatient department of the All India Institute of Medical Sciences, New Delhi, with signs and symptoms of vaginitis. Vaginal discharge was collected from the posterior fornix of the vagina of each woman with two cotton tipped sterile swabs on at least three separate occasions. At each visit one swab was immediately inoculated into $2 \mathrm{ml}$ Diamond's axenic culture medium and incubated at $37^{\circ} \mathrm{C} .^{21}$ The other swab was rolled in normal saline over a slide, and the wet mount was examined by light microscopy for the presence of $T$ vaginalis. The culture tubes were examined daily for seven days for the presence of motile trichomonads before being considered as giving negative results. One of the isolates was maintained by serial biweekly cultures for raising antiserum and preparing antigen for various serological tests. Patients consisted of 58 women with frothy vaginal 
discharge who were positive for $T$ vaginalis by wet mount examination or culture of vaginal discharge, or both. The control group consisted of 48 age matched women with clinical signs of vaginitis, but negative results for $T$ vaginalis in smear or culture, or both.

\section{INDIRECT HAEMAGGLUTINATION ASSAY (IHA)}

This assay was performed according to the technique described by Mc Enteggart et $a^{l^{2}}$ with slight modifications.

\section{IHA with polysaccharide antigens}

Antigen preparation-Carbohydrate antigen was prepared using Fuller's formamide extraction procedure. ${ }^{23}$ Briefly, saline washed parasites from $50 \mathrm{ml}$ of a 48 to 72 hour old culture of $T$ vaginalis were suspended in $1 \mathrm{ml}$ formamide and heated at $150^{\circ} \mathrm{C}$ for 10 minutes after the addition of $2.5 \mathrm{ml}$ acid alcohol (95 parts absolute ethanol and five parts of hydrochloric acid $2 \mathrm{~mol} / \mathrm{l}$. After the mixture had been centrifuged at $900 \times g$ for 30 minutes, the sediment was dissolved in $1 \mathrm{ml}$ physiological saline and the $\mathrm{pH}$ adjusted to 7 . The working dilution of the antigen was found by chequer board titration.

Control serum sample-Two adult New Zealand rabbits were given six injections of live $T$ vaginalis, each consisting of $10^{7}$ organisms in $1 \mathrm{ml}$ physiological saline, over a three week period. One week after the last injection hyperimmune serum samples, which gave positive results by IHA at a 1:60 dilution, were collected. Serum from a six month old infant, which had been adsorbed with $T$ vaginalis, was used as negative control serum.

Test procedure-A $2 \%$ suspension of saline washed sheep red blood cells (SRBC) was sensitised with a working dilution of the antigen at $37^{\circ} \mathrm{C}$ for four hours. Serum samples to be tested, including those from the controls, were adsorbed overnight with SRBC and then inactivated at $56^{\circ} \mathrm{C}$ for 30 minutes. Doubling dilutions were made in physiological saline in microtitre plates at $0.05 \mathrm{ml}$ volume per well, followed by $0.025 \mathrm{ml}$ of sensitised SRBC. The plates were incubated at $37^{\circ} \mathrm{C}$ for one hour and at $4^{\circ} \mathrm{C}$ overnight. The end point was the dilution yielding at least $50 \%$ haemagglutination, as shown by carpeting in the wells. Any serum giving a positive result at a 1:15 dilution was identified as giving a positive reaction.

\section{IHA with protein antigen}

An IHA with crude extract antigen of $T$ vaginalis was performed by a method similar to that for Entamoeba histolytica. ${ }^{24}$ The control serum samples were the same as in the assay with polysaccharide antigen.
Antigen preparation-Saline washed parasites from $50 \mathrm{ml}$ of a 48 to 72 hour culture of $T$ vaginalis were suspended in $1 \mathrm{ml}$ phosphate buffered saline (PBS),

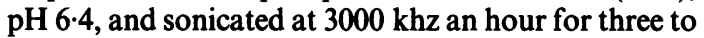
five minutes. The preparation was centrifuged at $15000 \times g$ for 15 minutes at $4^{\circ} \mathrm{C}$, and the clear supernate was used as the antigen. The working dilution of the antigen was estimated by chequer board titration.

Test procedure-A $2.5 \%$ suspension of tanned SRBC was sensitised with the working dilution of antigen at $25^{\circ} \mathrm{C}$ for 30 minutes. The test procedure and interpretation of the results were similar to those described for the assay with polysaccharide antigen.

ENZYME LINKED IMMUNOSORBENT ASSAY (ELISA) Conjugated antiserum-Rabbit antihuman immunoglobulin conjugated with horseradish peroxidase was obtained from Dakopatts (Switzerland). Preliminary titration of the conjugated antiserum with human immunoglobulin showed that the optimum dilution that could be used was 1:1600.

Antigen preparation-Saline washed parasites from $50 \mathrm{ml}$ of 72 hour culture of $T$ vaginalis were suspended in $1 \mathrm{ml} 0.5 \mathrm{~mol} / 1$ carbonate buffer, $\mathrm{pH} 9.6$, and sonicated briefly on three occasions using the methods already described. The protein content of the extract was found to be $6.75 \mathrm{mg} / \mathrm{ml}$ by Lowry's method. ${ }^{25}$ By using gradually diminishing concentrations of antigen and different dilutions of several positive and negative serum samples, the working concentration of the antigen was found to be $50 \mathrm{ng}$ $\operatorname{protein} / \mathrm{ml}$.

Control sera-One of the test serum samples giving positive results by both IHAs at high dilutions was used as the positive control serum. The negative control serum was the same as that used in both IHAs.

Test procedure-Leaving the first vertical row blank as a control, all other wells of micro ELISA plate (Linbro, Flow Laboratories) were coated overnight with $100 \mu \mathrm{l}$ working dilution of the antigen. This was followed by thorough washing in PBS-Tween 20 (PBS pH 7.4 with $0.5 \%$ polysorbate 20 (Tween 20 )), which we used for washing and dilution. Unbound sites were blocked by $3 \%$ bovine serum albumin $100 \mu \mathrm{l}$ for two hours, and then plates were washed thoroughly. All the sera were tested at a 1:100 dilution. The covered plates were kept at $25^{\circ} \mathrm{C}$ for four hours and then washed thoroughly. Each well of the plate was incubated with $100 \mu \mathrm{l}$ of the optimum dilution of conjugated antiserum at $25^{\circ} \mathrm{C}$ overnight and then washed thoroughly. Freshly prepared $0.04 \%$ ortho- 
phenylene diamine in phosphate citrate buffer, $\mathrm{pH} 5.0$, containing hydrogen peroxide was added to each of the wells in $100 \mu$ l volumes. After 15 minutes incubation in the dark at room temperature, the reaction was stopped with $100 \mu \mathrm{l}$ of sulphuric acid $2 \mathrm{~mol} / \mathrm{l}$. The plates were read at $492 \mathrm{~nm}$ in a Flow Titretek ELISA reader. Any serum sample with an absorbance value greater than half the sum of those of positive and negative controls was taken as positive.

\section{RADIOIMMUNOPRECIPTATION OF SURFACE ANTIGENS}

The parasites from a 48 hour culture of $T$ vaginalis were washed three times in PBS, $\mathrm{pH} 7 \cdot 2$, and the parasite count was adjusted to $6 \times 10^{5}$ parasites per $0.2 \mathrm{ml}$ volume.

Iodination-Surface iodination was carried out using the iodogen method. ${ }^{26}$ The inner surface of a $10 \times 30 \mathrm{~mm}$ glass tube was coated with $10 \mu \mathrm{g}$ iodogen (Pierce Chemicals, USA) dissolved in $0.5 \mathrm{ml}$ chloroform. The choloroform was allowed to evaporate leaving a coat of iodogen on the inner surface of the tubes. In it $500 \mu \mathrm{Ci}$ carrier free radioactive iodine ( $\left.{ }^{125} \mathrm{I}\right)$ (Amersham, England) was incubated (with intermittent shaking) with $5 \times 10^{6}$ living parasites for 10 minutes. The variability of the parasites was checked under a microscope. More than $95 \%$ of the parasites were found to be motile at the end of iodination. They were transferred to another tube and washed three times in PBS, pH 7.2, to remove free iodine.

The membrane proteins were solubilised using a solution containing $10 \mathrm{mmol} / \mathrm{l}$ phenyl methyl sulphonyl fluoride (PMSF), $5 \mathrm{mmol} / \mathrm{l}$ iodoacetamide, $10 \%$ Triton X-100, and $5 \%$ sodium deoxycholate in physiological saline. The preparation was centrifuged at $10000 \mathrm{rpm}$ for 20 minutes to remove all the insoluble material.

Radioimmunopreciptation-Protein A Sepharose (Pharamacia, Upsala, Sweden) was swollen in TRIS (trometanol) and hydrochloric acid $(0.5 \mathrm{~mol} / 1$ with $0.15 \mathrm{~mol} / 1$ sodium chloride), $\mathrm{pH} 8 \cdot 2$. It was incubated with each patient's serum for one hour. The resulting protein A Sepharose antibody complexes were packed into Eppendorff tip columns and incubated for one hour with $100 \mu \mathrm{l}$ antigen (count adjusted to $1 \times 10^{6}$ counts per minute $(\mathrm{cpm}) / \mathrm{ml})$. After being washed with a 50 column volume of TRIS and hydrochloric acid with Triton X-100, the antigen antibody complexes were eluted in $50 \mu \mathrm{l}$ glycine hydrochloric acid buffer, $\mathrm{pH} 2 \cdot 3$, radioactivity was counted, and they were neutralised to $\mathrm{pH} 7 \cdot 0$. Controls (a known negative serum, a positive serum, and antigen) were passed through a protein A Sepharose column.

SODIUM DODECYL SULPHATE-POLYACRYLAMIDE GEL ELECTROPHORESIS (SDS-PAGE) AND AUTORADIOGRAPHY

The eluates, antigen, and molecular weight markers were analysed by polyacrylamide gel electrophoresis (PAGE) with $10 \%$ sodium dodecyl sulphate (SDS) under reducing conditions. ${ }^{27}$ The gel was stained with Coommassie brilliant blue R 450 (Sigma), destained, dried, and exposed to a NS 2T Kodak $X$ ray film with enhancer screen. The film was developed using 19D developer.

\section{Results}

In wet mount preparations of vaginal discharge the parasites remained actively motile for about three hours at room temperature. In culture tubes they could easily be detected in eight of the 58 patients by 24 hours and in 41 by 48 hours. Smear and culture positivity was taken as the standard against which all other tests were compared. Either one or both of them were regarded as diagnostic for trichomoniasis.

Table 1 Positive serological results in patients positive by smear or culture, or both

\begin{tabular}{|c|c|c|c|c|c|}
\hline \multirow[b]{2}{*}{$\begin{array}{l}\text { Positive } \\
\text { biological } \\
\text { test results }\end{array}$} & \multirow[b]{2}{*}{ No } & \multicolumn{3}{|c|}{ Positive by IHA using: } & \multirow[b]{2}{*}{$\begin{array}{l}\text { Positive } \\
\text { by } \\
\text { ELISA }\end{array}$} \\
\hline & & $\begin{array}{l}\text { Polysac- } \\
\text { charide } \\
\text { antigen }\end{array}$ & $\begin{array}{l}\text { Protein } \\
\text { antigen }\end{array}$ & $\begin{array}{l}\text { Both } \\
\text { antigens }\end{array}$ & \\
\hline $\begin{array}{l}\text { Smear } \\
\text { Culture } \\
\text { Smear and culture }\end{array}$ & $\begin{array}{r}3 \\
11 \\
44\end{array}$ & $\begin{array}{l}0 \\
4 \\
18(41)\end{array}$ & $\begin{array}{c}3 \\
3 \\
21(48)\end{array}$ & $\begin{array}{l}0 \\
2 \\
13(30)\end{array}$ & $\begin{array}{c}3 \\
4 \\
29(66)\end{array}$ \\
\hline
\end{tabular}

IHA $=$ Indirect haemagglutination assay.

ELISA = Enzyme linked immunosorbent assay.

Table 2 Comparison of results of serological tests for antibodies to Trichomonas vaginalis

\begin{tabular}{|c|c|c|c|c|c|c|}
\hline & & \multicolumn{3}{|c|}{ Positive in IHA with: } & \multirow[b]{2}{*}{$\begin{array}{l}\text { Positive } \\
\text { by ELISA }\end{array}$} & \multirow[b]{2}{*}{$\begin{array}{l}\text { Positive } \\
\text { in all }\end{array}$} \\
\hline & & $\begin{array}{l}\text { Polysaccaride } \\
\text { antigen }\end{array}$ & $\begin{array}{l}\text { Protein } \\
\text { antigen }\end{array}$ & $\begin{array}{l}\text { Both } \\
\text { antigens }\end{array}$ & & \\
\hline $\begin{array}{l}\text { Patients } \\
\text { Controls } \\
\text { Difference }\end{array}$ & $\begin{array}{l}58 \\
48\end{array}$ & $\begin{array}{c}22(38) \\
6(13) \\
p=0.005\end{array}$ & $\begin{array}{c}27(47) \\
7(15) \\
p=0.001\end{array}$ & $\begin{array}{l}15(26) \\
2(4) \\
p=0.005\end{array}$ & $\begin{array}{l}36(62) \\
26(54) \\
N S\end{array}$ & $\begin{array}{l}15(26) \\
2(4) \\
p=0.005\end{array}$ \\
\hline
\end{tabular}

For meanings of abbreviations see table 1 . 


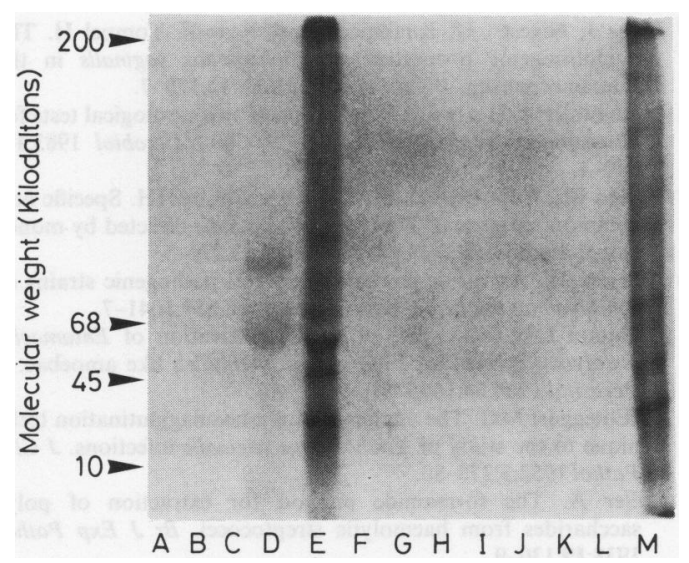

Figure Autoradiograph of radioimmunoprecipitates analysed in $10 \%$ sodium dodecyl sulphate-polyacrylamide gel electrophoresis under reducing conditions. Lane $A=$ control cord serum preabsorbed by Trichomonas vaginalis; lanes $B$ to $L=$ patients sera with antibody to $T$ vaginalis by indirect haemagglutination and enzyme linked immunosorbent assays; lane $M=$ solubilised surface radioiodinised parasite.

Of 58 patients with a definitive diagnosis, 44 were positive by both smear and culture, three by smear alone, and 11 by culture alone (table 1). We found antibodies to trichomonads by IHA using polysacharide in 22 patients and using crude extract antigens in 27 (table 2), which were significantly ( $p<0.005$ and $p<0.001)$ more than the numbers of controls with antibodies. In the ELISA 36 patients and 26 controls were found to be positive, not a significant difference.

When IHAs with either antigen were considered together only 15 patients and two controls gave positive results. If the ELISA was considered with the IHA the results did not change.

The figure shows antigenic analysis by SDS-PAGE. Of the 11 patients tested, only two showed an immunological reaction with surface protein antigens. Seven bands were detected in the semen of one patient and three in that of the other.

\section{Discussion}

In the present study $58(55 \%)$ out of 106 randomly collected cases of vaginitis were found to be associated with $T$ vaginalis. This indicates the high prevalence of trichomoniasis in India. Comparable figures have been found by other workers from different parts of the world. ${ }^{1228}$ Trichomoniasis is therefore probably one of the most common sexually transmitted diseases in many parts of the world. Culture and smear examinations are probably the best way to diagnose $T$ vaginalis infection, although culture was found to be more sensitive (though not significantly so) than smear examination in our study. This finding corroborates earlier work that found culture to be more sensitive than smear examination. 112829

In this study the IHA using either polysaccharide antigen or crude antigen extract detected antibodies in about $25 \%$ of cases. It was, however, highly specific (table I) ( $p<0.001$ and $p<0.005)$. Though previous workers had predicted that results may be different when both antigens are used, use of polysaccharide antigen or crude extract antigen made little difference in the IHA as far as sensitivity or specificity was concerned. Even though the ELISA was found to be slightly more sensitive than the other two tests, it was the least specific, giving positive results in half the control population.

Thus none of the immunodiagnostic tests have either the sensitivity or the specificity of culture and smear examination for diagnosing trichomoniasis. In the present study, however, culture positivity did not further increase seropositivity for trichomoniasis.

Several explanations can be given for the low seropositivity in trichomoniasis. The assays used were possibly insufficiently sensitive to detect antibody. Furthermore, as trichomonal vaginitis is mainly a surface infection, little mucosal antibody gains access to the systemic circulation. The second explanation may be that in the early stages of infection, when parasites can be detected in smears or culture, or both, antibodies were not produced.

Though the serological tests, apart from the ELISA, were found to be highly specific, several explanations can be given for the few false positive results detected. These may have been caused by resolved past $T$ vaginalis infection, the presence of natural antibodies against $T$ vaginaliis, or the presence of cross reacting antigens between $T$ vaginalis and other intestinal trichomonads, such as Pentatrichomonas hominis. ${ }^{190-32}$

As none of the serological tests were found to be sensitive or specific enough, we tried to find a surface antigen that can be purified and used to develop a more sensitive and specific test. Radioimmunoprecipitation of the surface antigens with sera from several seropositive patients, however, did not show reactions with any protein antigen except in two patients. The antigenic stimulus is therefore probably given by surface molecules other than proteins. This leads to the belief that the exposed carbohydrate antigens on the surface may be associated with decreased systemic immunogenicity of the parasite. In addition immunity may be primarily local, associated with a secretory $\operatorname{IgA}$ response without a good systemic immune response, which would lead to the inability of the immunodiagnostic tests to detect $T$ vaginalis infestation.

\section{References}

1 Rein MF, Chapel TA. Trichomoniasis, candidiasis, and the minor 
venereal diseases. Clin Obstet Gynecol 1975;18:73-88.

2 Spence MR, Hollander DH, Smith J, McCaig L, Sewell D, Brookman M. The clinical and laboratory diagnosis of Trichomonas vaginalis infection. Sex Transm Dis 1980;7:168-71.

3 Bloom BR. Games parasites play: how parasites evade immune surveillance. Nature 1979;279:2-26.

4 Honigberg BM. Trichomonads of importance in human medicine. In: Krier JR, ed. Parasitic protozoa. London: Academic Press, 1978. Vol 2, chapter 4:276-424.

5 Kreiger JN. Urologic aspects of trichomoniasis. Invest Urol 1981;18:411-7.

$6 \mathrm{Su}$ KE. Antibody to Trichomonas vaginalis in human cervicovaginal secretions. Infect Immun 1982:37:852-7.

7 Green RL, Scales RW, Kraus SJ. Increased serum IgE concentration in venereal diseases. British Journal of Venereal Diseases 1976;52:257-60.

8 Honigberg BM, Goldman M. Immunologic analysis by quantitative fluorescent antibody methods of the effects of prolonged cultivations on Trichomonas galinae. J Protozool 1968;15: 176-84.

9 Landolfo S, Martinotti MG, Martinetto P, Forni G. Natural cellmediated cytotoxicity against Trichomonas vaginalis in the mouse. I. Tissue, strain, age distribution, and some characteristics of the effector cells. J Immunol 1980;124:508-14.

10 Morton RS. Metronidozole in the single dose treatment of trichomoniasis. British Journal of Venereal Diseases 1972:48:525-7.

11 Lowe GH. The trichomonads. London: HMSO, 1978. Public Health Laboratory Service monograph series No 9; 1-44.

12 Greenwood JR, Kirk-Hillaire K. Evaluation of acridine orange stain for detection of Trichomonas vaginalis in vaginal specimens. J Clin Microbiol 1981;14:699.

13 Kuberski T. Evaluation of indirect haemagglutination test for study of Trichomonas vaginalis infection particularly in man. Sex Transm Dis 1978;3:97-102.

14 Street DA, Taylor-Robinson D, Ackers JP, Hanna NF, McMillan A. Evaluation of an enzyme linked immunosorbent assay for the detection of antibodies to Trichomonas vaginalis in sera and vaginal secretions. British Journal of Venereal Diseases 1982;58:330-3.

15 Mason PR. Serodiagnosis of Trichomonas vaginalis infection by the indirect fluorescent antibody test. J Clin Pathol 1979;32:1211-5.

16 Jaakmees H, Teras J, Roigas F, Nigesen U, Tompel H. Complement fixing antibodies in the blood sera of man infested with Trichomonas vaginalis. Wiad Parazytol 1966;12:378-84.
17 Teras J, Nigesen U, Kaakmees H, Roigas F, Tompel H. The agglutinogenic properties of Trichomonas vaginalis in the human organism. Wiad Parazytol 1966;12:370-7.

18 Mathews HM, Healy GR. Evaluation of two serological tests for Trichomonas vaginalis infection. J Clin Microbiol 1983;17: 840-3.

19 Torian BE, Connelly RJ, Stephens RS, Stibbs HH. Specific and common antigens of Trichomonas vaginalis directed by monoclonal antibodies. Infect Immun 1984;43:270-5.

20 Alderete JF. Antigenic analysis of several pathogenic strains of Trichomonas vaginalis. Infect Immun 1983;39:1041-7.

21 Diamond LS. Techniques of axenic cultivation of Entamoeba histolytica Schaudinn 1903 and $E$ histolytica like amoebae. $J$ Parasitol 1968;54:1045-56.

22 McEnteggart MG. The application of a haemagglutination technique to the study of Trichomonas vaginalis infections. $J$ Clin Pathol 1952;5:275-80.

23 Fuller A. The formamide method for extraction of polysaccharides from haemolytic streptococci. Br J Exp Pathol 1938;19:130-9.

24 Kessel JF, Lewis WP. Pasquel CM, Turner JA. Indirect haemagglutination test and complement fixation test in amebiasis. $\mathrm{Am} \mathrm{J}$ Trop Med Hyg 1965;14:540.

25 Lowry OH, Rosenbrough NJ, Farr AL, Randall RJ. Protein measurement with Folin Phenol reagent. J Biol Chem 1951;192:265-75.

26 Markwell MAK, Fox CF. Surface specific iodination of membrane proteins of vir and ecikaoyotic cells using 1,3,4,6 tetrachloro-3 alphn, 6 alfa-diphenyl glycoluril. Biochemistry 1978;17:4807-17.

27 Laemmli UK. Clevage of structural proteins during the assembly of the head of bacteriophage T4. Nature 1970;227:680.

28 Ghose HK, Douglas GR. Comparison of wet mount stained smears and culture in detecting Trichomonas in vaginitis. $M e d J$ Aust 1983;1:404.

29 Fouts AC, Kraus SJ. Trichomonas vaginalis, reevaluation of its clinical presentation and laboratory diagnosis. $J$ Infect Dis 1980;141:137-43.

30 Honigberg BM. Tricomonads. In: Jackman GJ, Herman R, Singer L, eds. Immunity to parasitic animals. New York: Appleton, 1970, Vol 2:469-550.

31 Bennett BD, Bailey J, Gardner WA Jr. Immunocytochemical identification of trichomonands. Arch Pathol Lab Med 1980;104:247-9.

32 Kott H, Adler S. A serological study of Trichomonas species parasitic in man. Trans $R$ Soc Trop Med Hyg 1961;55:33-44. 